\title{
A Study on Smart Phone Use Condition of Infants and Toddlers
}

\author{
Yu-Mi Baek ${ }^{1}$, Jeong-Min Lee ${ }^{2}$ and Kyu-Soo Kim ${ }^{3}$ \\ ${ }^{1}$ Yu-Mi Baek. Professor, Dept. of Education Counseling and Psychology Graduate \\ School of Cyber, Joong-bu University \\ ${ }^{2}$ Jeong-Min Lee. Ph.D., Early Childhood Education, WonKwang University \\ ${ }^{3}$ Kyu-Soo Kim. Professor, Department of Early Childhood Education, \\ Wonkwang University \\ 2endend798@gmail.com
}

\begin{abstract}
This study investigated the smart phone use condition of infants and toddlers, and mothers' perception of their children's smart phone use, including the role of a mother's parental efficacy in making difference in the smart phone use condition of infants and toddlers. Parents whose children go to childhood education institutes in D and I cities were selected as research subjects. The total number of the children was 500, and with collected data, frequency analysis and difference verification were carried out by using SPSS program. The results of study showed that infants and toddlers most frequently used smart phones at home with their mothers, and toddlers used smart phones more than infants did, and infants and toddlers used smart phones 'less than 5 times a week', with average 1hours a day. Secondly, analysis of mothers' perception of infants and toddlers' smart phone use indicated that the need of their children was the most influential factor. And mothers who said their kids needed a smart phone considered it a useful learning tool, but others opposed smart phone use because of its negative effects on children's physical and cognitive development. Among many programs, cartoon animation was most frequently used with smart phones, contrary to the infrequent use of educational contents. Thirdly, the difference in smart phone use condition according to parental efficacy of mother showed that there was a significant difference between the number of use and average use hours.
\end{abstract}

Keywords: Infants and toddlers, Smart phone use condition, Parental Efficacy

\section{Introduction}

Over past 20 years, human beings have experienced a huge paradigm shift from traditional industrial society to digital society. Mobile devices have been at the center of this change, bringing totally different life style. If the spread of cellular phones was the first big bang, the spread of smart phones among the public can be the second big bang. Smart phones, the state -of- the- art mobile phones, have been developed to the extent that the internet can be available like computer [8].

Smart phones found their way into households, and under a changed educational environment, the excellent accessibility, mobility, and convenience of mobile devices brought about frequent exposure to smart phones. A smart phone is a versatile cell phone that has communication and network functions, including the existing voice call function, and is able to mange schedule and personal information like PDA (Personal Digital Assistant) [7]. According to research on the actual condition conducted by Korea Internet Security Agency (2010) showed that people tended to replace cell phones with smart phones (94.8\%), and 97.0\% of Korea households used 'cell phone' service. People in a range of age groups had smart phones, and $87.0 \%$ of people aged over three used them. 
The development and increased use of smart phones make it easier for infants and toddlers to be exposed to smart phones, and it is possible to access the internet every time and everywhere. Especially, smart phones and PCs [1] have the same structure and features in view of technology. But from users' point of view, smart phones have a touch screen controlled by fingers and are manufactured in an intuitive and simple way. This is why not only middle aged and elderly adults but also infants and toddlers who found it difficult to handle a laptop or PC by using a keyboard and mouse feel comfortable when using a smart phone [4]. Therefore, infants and toddlers can be naturally exposed to smart phones at home with their mothers. With smart phones, they listen to children's song, watch videos, play games, and use educational applications. But there is a chance to experience some contents that are not suitable for kids. Regarding this issue, some studies focused on the educational effects of smart phones [11], but some researchers expressed concerns about addictive use of smart phones [6]. Though different opinions about smart phones are suggested, basic studies on exposure frequency, place, time, and way of smart phone use have not been actively conducted yet. In infancy and early childhood, children build attachment relations with their mother. Among a variety of factors which have influence on a body, emotion, and cognition of human beings during one's entire life, a mother, in particular, has an effect on a lot of parts of development process of infants and toddlers. Infants and toddlers absolutely need adult's intervention because they lack of judgment and self-control on time, compared to adolescents and adults. Although cognitive and emotional efficacy of mother has implications for their children's number of use and use hours of smart phones, there is no study on this matter. In this context, preceding research of young children's game addiction selected children's age, sex, and parents as variables that influence on young children's addiction. In addition, most of the research is limited to middle and high school $[2,9]$, which leads to the lack of study on young children. It is easy to put emphasis on parents with regard to possession of cellular phones and choose middle or high school students as objects of study because of difficulty of selection. However, smart phones spread quickly among infants and toddlers, without particular restraints of parents. And unlike computers, they can easily provide lots of raw information like texts and videos, regardless of time and space, which means smart phones are more dangerous than the internet or TV in terms of addiction.

This study thinks highly of mother, the influential factor on young children in infancy and early childhood when young children are exposed to smart phones in a number of ways. And the study tries to investigate the smart phone use condition of infants and toddlers, mothers' perception of their children's smart phone use, and the difference in the smart phone use condition of infants and toddlers according to parental efficacy of mother. Through this, this study aims to understand mothers' perception of young children's smart phone use and provide basic information to prevent parents or childhood education institutes’ uncritical and irresponsible acceptance of smart phone use.

Subjects for inquiry according to the purpose of this study are as follows.

Subject for inquiry 1. What is the smart phone use condition of infants and toddlers?

Subject for inquiry 2. What is the mothers' perception of their young children's smart phones use?

Subject for inquiry 3. Does parental efficacy of mother make difference in smart phone use condition of infants and toddlers?

\section{Study Method}

\subsection{Study Subjects}

The study subjects of this work were mothers of 500 infants and young children going to child education institutes in D and I. During the full month of October 2012, with the 
help of the directors and teachers of the institutes, questionnaire copies were distributed to each home, and then were collected. 488 questionnaire copies excluding copies with no answers and insincere answers were finally chosen for an analysis. The general backgrounds of the study subjects are presented in Table 1.

Table 1. General Backgrounds of Infants, Young Children and their Mothers

\begin{tabular}{|c|c|c|c|c|}
\hline \multicolumn{2}{|c|}{ Background factors } & \multirow{3}{*}{$\begin{array}{l}\text { Type } \\
\text { Male } \\
\text { Female }\end{array}$} & \multirow{3}{*}{$\begin{array}{l}\text { People (\%) } \\
261(53.7) \\
225(46.3)\end{array}$} & \multirow{3}{*}{$\begin{array}{c}\text { Total (\%) } \\
488(100.0)\end{array}$} \\
\hline Background & & & & \\
\hline \multirow{3}{*}{$\begin{array}{l}\text { factors of infants } \\
\text { and young } \\
\text { children }\end{array}$} & sex & & & \\
\hline & \multirow{2}{*}{ Age } & Less than 3 years & $113(24.8)$ & \multirow{2}{*}{$456(100.0)$} \\
\hline & & Between 3 and 6 & $343(75.2)$ & \\
\hline \multirow{13}{*}{$\begin{array}{l}\text { Background } \\
\text { factors of } \\
\text { mothers }\end{array}$} & \multirow{4}{*}{ Age } & Less than 30 years & $42(8.7)$ & \multirow{4}{*}{$482(100.0)$} \\
\hline & & Between 31 and 35 & 231(47.9) & \\
\hline & & Between 36 and 40 & 173(35.9) & \\
\hline & & Over 41 years & $36(7.5)$ & \\
\hline & \multirow{4}{*}{ Education } & $\begin{array}{l}\text { Graduation from high school or } \\
\text { lower }\end{array}$ & 83(17.3) & \multirow{4}{*}{$481(100.0)$} \\
\hline & & Graduation from college & $118(24.5)$ & \\
\hline & & Graduation from university & $230(47.8)$ & \\
\hline & & $\begin{array}{l}\text { Graduation from graduate } \\
\text { school or more }\end{array}$ & $50(10.4)$ & \\
\hline & \multirow{2}{*}{ Job } & Yes & $253(52.9)$ & \multirow{2}{*}{$478(100.0)$} \\
\hline & & No & $225(47.1)$ & \\
\hline & \multirow{3}{*}{$\begin{array}{l}\text { Monthly income } \\
\text { on average }\end{array}$} & From 2 to 3 million KRW & $154(36.4)$ & \multirow{3}{*}{$423(100.0)$} \\
\hline & & From 3 to 4 million KRW & 155(36.6) & \\
\hline & & From 4 to 5 million KRW & $114(27.0)$ & \\
\hline
\end{tabular}

\subsection{Measurement Tool}

To look into the actual state of smartphone use of infants and young children, this work investigated previous studies and on the basis of the investigation, prepared questionnaire about the actual state of smartphone use of infants and young children. The questionnaire consists of questions about the actual state of smartphone use of infants and young children, about mothers' recognition of the smartphone use of their infants and young children, and about mothers' child-rearing efficacy. For validity of the questionnaire, 2 professors of child education and three kindergarten teachers who have M.A. of child education checked and changed the questions of the questionnaire.

\subsection{Analysis Method}

To look into the actual state of smartphone use of infants and young children, mothers' recognition of smartphone use of infants and young children, and the different actual state of smartphone use of infants and young children depending on mothers' child-rearing efficacy, this work conducted frequency analysis and difference test.

\section{Study Result}

\subsection{The Actual State of Smartphone Use of Infants and Young Children}

Table 2 presents the actual state of smartphone use of infants and young children. The question about the person who is mainly with when infants and young children use smartphone revealed that there is correlation between the age of infants and young children and the person who is mostly with when they use smartphone. More specifically, the person who is together with was found to be mother (73\%), none (55.2\%), siblings (42.5), and father(29.3\%), and the highest response of infants was 'siblings', and that of young children was 'mother'. According to the question about the place where they use 
smartphone, it was found that there is correlation between the age and sex of infants and young children and the use place. More specifically, the highest response was 'home', the next highest ones in order were 'commercial facilities (e.g., coffee shops, restaurants, marts)', 'regardless of places', and 'transportations for moving'. It was found that female infants and young children used smartphone more than male ones in other places than home, and that young children used smartphone more than infants 'regardless of places'. In addition, it was found that the frequency of smartphone use has correlation with the age of infants and young children. More specifically, it was found that young children used smartphone more than infants. Nevertheless, for infants, the response of 'less than 5 times a week' accounted for $57.9 \%$, which means that over a half of infants used smartphone. Also, the response of 'more than once a way' accounted for $15 \%$. According to the question about the average hours of smartphone use, most subjects replied 'one hour', and $35 \%$ replied 'more than two hours, and the average use hours of male infants and young children were higher than that of female ones.

Table 2. The Actual State of Smartphones use of Infants and Young Children

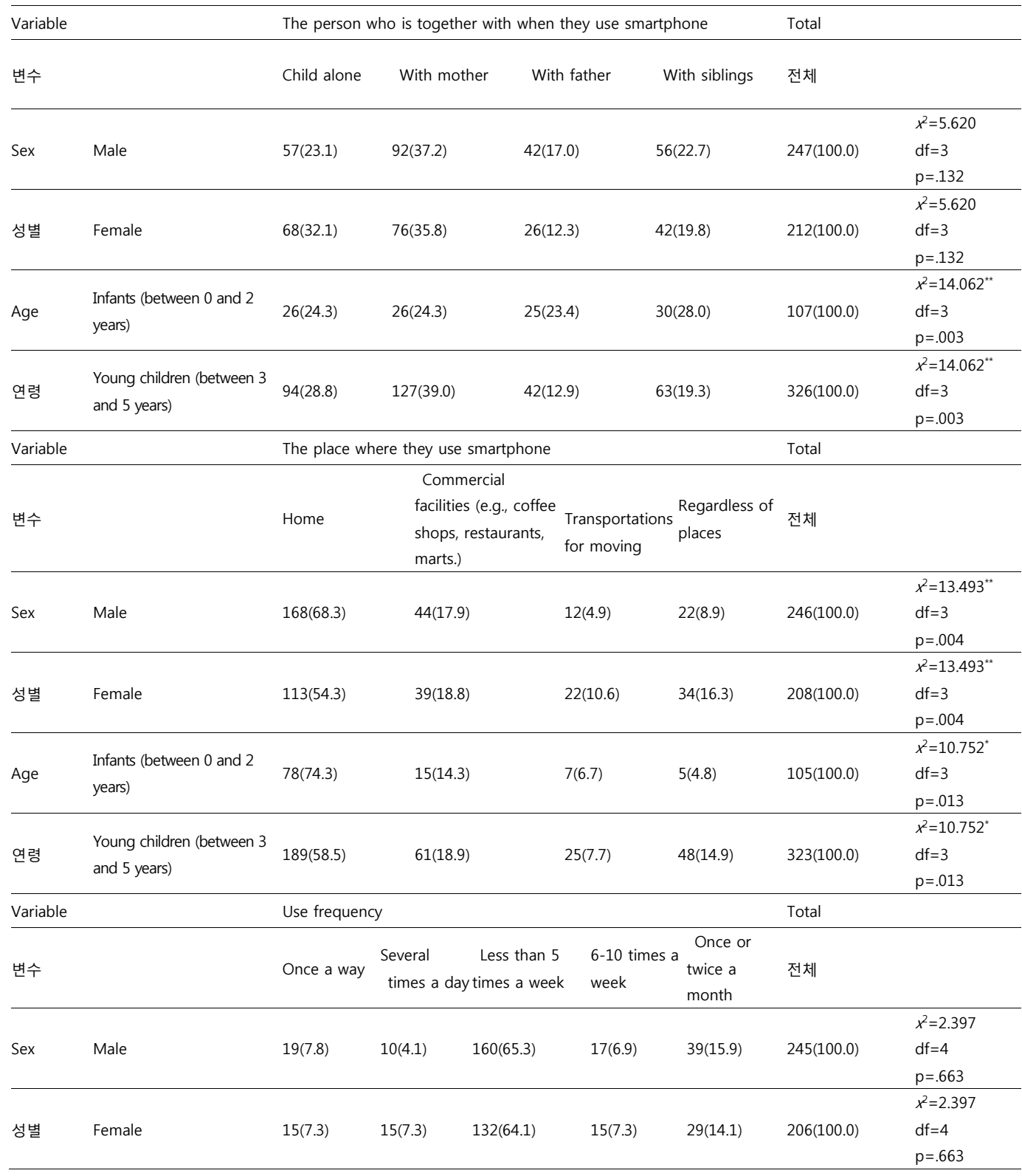




\begin{tabular}{|c|c|c|c|c|c|c|c|c|}
\hline Age & $\begin{array}{l}\text { Infants (between } 0 \text { and } 2 \\
\text { years) }\end{array}$ & $5(4.7)$ & $3(2.8)$ & $62(57.9)$ & $12(11.2)$ & $25(23.4)$ & 107(100.0) & $\begin{array}{l}x^{2}=14.133^{* *} \\
d f=4 \\
p=.007\end{array}$ \\
\hline 연령 & $\begin{array}{l}\text { Young children (between } 3 \\
\text { and } 5 \text { years) }\end{array}$ & $25(7.9)$ & $19(6.0)$ & $217(68.2)$ & $17(5.3)$ & $40(12.6)$ & $318(100.0)$ & $\begin{array}{l}x^{2}=14.133^{* *} \\
d f=4 \\
p=.007\end{array}$ \\
\hline Variable & & \multicolumn{3}{|c|}{ Average use hours } & & & Total & \\
\hline 변수 & & 1 hour & & 2 hours & \multicolumn{2}{|c|}{3 hours } & 전체 & \\
\hline Sex & Male & $55(63.2)$ & & $21(24.1)$ & \multicolumn{2}{|c|}{$11(12.6)$} & $87(100.0)$ & $\begin{array}{l}x^{2}=.062 \\
d f=2 \\
p=.970\end{array}$ \\
\hline 성별 & Female & $43(65.2)$ & & $15(22.7)$ & \multicolumn{2}{|c|}{$8(12.1)$} & $66(100.0)$ & $\begin{array}{l}x^{2}=.062 \\
d f=2 \\
p=.970\end{array}$ \\
\hline Age & $\begin{array}{l}\text { Infants (between } 0 \text { and } 2 \\
\text { years) }\end{array}$ & $22(64.7)$ & & $9(26.5)$ & \multicolumn{2}{|c|}{$3(8.8)$} & $34(100.0)$ & $\begin{array}{l}x^{2}=.490 \\
d f=2 \\
p=.783\end{array}$ \\
\hline 연령 & $\begin{array}{l}\text { Young children (between } 3 \\
\text { and } 5 \text { years) }\end{array}$ & $70(64.2)$ & & $25(22.9)$ & \multicolumn{2}{|c|}{$14(12.8)$} & 109(100.0) & $\begin{array}{l}x^{2}=.490 \\
d f=2 \\
p=.783\end{array}$ \\
\hline & Total & $92(64.3)$ & & $34(23.8)$ & \multicolumn{2}{|c|}{ 17(11.9) } & $143(100.0)$ & \\
\hline
\end{tabular}

\subsection{Mothers' Recognition of Smartphone use of Infants and Young Children}

Table 3 presents mothers' recognition of smartphone use of infants and young children. According to the question as to whether the smartphone use of infants and young children is needed, 53.3\% responded that 'it is needed', and $45.9 \%$ responded that it is not needed'. According to the question as to why infants and young children need smartphone (multi-answers allowed), the following results were drawn: because the smartphone use is helpful in the aspect of learning (47.7\%); because it is needed to follow the trend (42.2\%); because infants and young children don't bother their parents, and instead play by themselves (27.3\%); because it helps infants and young children get free of their fear of new devices (18.8\%). Mostly, mothers expect that smartphone will be able to help out their children in the aspect of learning, whereas $27.3 \%$ recognized that smartphone is a sort of toy.

According to the question as to why mothers think that their infants and young children don't' need smartphone (multi-answers allowed), the following results were drawn: because they are afraid of electro-magnetic wave and the visual disability of their children(77.6\%); because smartphone undermines the cognitive development (36.7\%); because their children are immature physically and cognitively(35.3\%); because smartphone undermines the social development (30.4\%); because their children can access harmful websites(26.2\%); because smartphone undermines the physical development (18.2\%); because smartphone undermines the brain development (14.3\%). It was found that mothers were afraid more of the obstruction of physical and cognitive development than of the social and psychological issue by the smartphone use of their children.

According to the question about the smartphone use conditions of infants and young children (multi-answers allowed), the following responses were drawn: because their children want to use smartphone (51.7\%); to deal with busy conditions of child-rearers (28.1\%); to soothe children (11.3\%); because there are some learning factors (11.3\%); to communicate on video (4.1\%). Although mothers responded that smartphone is needed in the aspect of learning, it was found that over a half of respondents, in fact, allowed their children to use smartphone if they wanted, and that mothers used smartphone to deal with their busy conditions and soothe their children.

According to the question about the program mainly used (multi-answers allowed), the following responses were drawn: cartoon videos such as Pororo and Tayo(63.0\%); 
shooting pictures and videos (48.5\%); children's stories and songs(33.0\%); games (29.1\%); educational contents (19.6\%); and smartphone icon media such as search for pictures and telephone numbers (18.9\%). It was found that their children use smartphone mainly to watch cartoon videos, and that listening to children's stories and songs and education application of contents in the aspect of learning were relatively low.

Table 3. Mother's Recognition of Smartphone use of Infants and Young Children

\begin{tabular}{|c|c|c|c|c|c|c|c|}
\hline \multirow{2}{*}{ Content } & \multicolumn{7}{|c|}{ Whether infants and young children need smartphone (people/\%) } \\
\hline & \multicolumn{4}{|l|}{ necessary } & \multicolumn{3}{|c|}{ unnecessary } \\
\hline People (\%) & \multicolumn{4}{|l|}{$256(53.3)$} & \multicolumn{2}{|l|}{$224(45.9)$} & \\
\hline \multirow[b]{2}{*}{ Content } & \multicolumn{7}{|c|}{ The reasons that infants and young children need smartphone (multi-answers allowed) } \\
\hline & \multicolumn{4}{|c|}{$\begin{array}{l}\text { because the smartphone use is } \\
\begin{array}{ll}\text { helpful in the aspect of } & \text { because it is needed } \\
\text { learning } & \text { to follow the trend }\end{array}\end{array}$} & \multicolumn{3}{|c|}{ 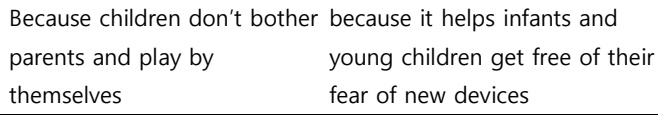 } \\
\hline People (\%) & \multicolumn{2}{|c|}{$61(47.7)$} & \multicolumn{2}{|l|}{$54(42.2)$} & $35(27.3)$ & \multicolumn{2}{|c|}{ 24(18.8) } \\
\hline \multirow[b]{2}{*}{ Content } & \multicolumn{7}{|c|}{ The reasons that infants and young children don't need smartphone (multi-answers allowed) } \\
\hline & \multicolumn{3}{|c|}{$\begin{array}{l}\text { because they are because } \\
\text { afraid of electro- smartphone } \\
\text { magnetic wave and undermines the } \\
\text { the visual disability of cognitive }\end{array}$} & \multicolumn{2}{|c|}{$\begin{array}{ll}\text { Because they are } & \text { because } \\
\text { immature } & \text { smartphone } \\
\text { physically and } & \text { undermines } \\
\text { cognitively } & \text { the social } \\
& \text { development }\end{array}$} & $\begin{array}{l}\text { because their } \\
\text { children can } \\
\text { access harmful } \\
\text { websites }\end{array}$ & $\begin{array}{ll}\text { smartphone } & \text { smartphone } \\
\text { undermines } & \text { undermines } \\
\text { the brain } & \text { the brain } \\
\text { development } & \text { development }\end{array}$ \\
\hline People (\%) & $222(77.6)$ & 105(36.7) & & $101(35.3)$ & $87(30.4)$ & $75(26.2)$ & $52(18.2)$ \\
\hline \multirow[b]{2}{*}{ Content } & \multicolumn{7}{|c|}{ The smartphone use conditions of infants and young children (multi-answers allowed) } \\
\hline & $\begin{array}{l}\text { because their } \\
\text { children want to } \\
\text { use smartphone }\end{array}$ & \multicolumn{3}{|c|}{$\begin{array}{l}\text { to deal with busy } \\
\text { conditions of child-rearers }\end{array}$} & to soothe children & $\begin{array}{l}\text { because there are } \\
\text { some learning } \\
\text { factors }\end{array}$ & $\begin{array}{l}\text { to communicate on } \\
\text { video }\end{array}$ \\
\hline People (\%) & 228(51.7) & $124(28.1)$ & & $50(11$. & & $50(11.3)$ & $18(4.1)$ \\
\hline \multirow[b]{2}{*}{ Content } & \multicolumn{7}{|c|}{ The main program used by infants and young children (multi-answers allowed) } \\
\hline & Cartoon videos & $\begin{array}{l}\text { Shooting } \\
\text { pictures and } \\
\text { videos }\end{array}$ & & $\begin{array}{l}\text { ren's stories } \\
\text { ongs }\end{array}$ & Games & $\begin{array}{l}\text { Educational } \\
\text { contents }\end{array}$ & $\begin{array}{l}\text { Smartphone icon media } \\
\text { (e.g., pictures) }\end{array}$ \\
\hline People (\%) & 286(63.0) & $220(48.5)$ & 150 & 3.0) & 132(29.1) & 89(19.6) & $86(18.9)$ \\
\hline
\end{tabular}

\subsection{The Differences in the Actual State of Smartphone use of Infants and Young Children Depending on Mothers' Child-rearing Efficacy}

Table 4 presents the differences in the actual state of smartphone use of infants and young children depending on mothers' child-rearing efficacy. Regarding the smartphone use state of infants and young children between the high and low groups of cognitive efficacy and emotional efficacy, there was no significant difference in the person who is together with at the time of using smartphone and the place where smartphone is used, but there were significant differences in the use frequency of smartphone and the average use hours of smartphone $\left({ }^{*} \mathrm{p}<.05{ }^{* *} \mathrm{p}<.01\right)$. More specifically, compared to the group that has high cognitive efficacy and emotional efficacy, the group that has low cognitive efficacy and emotional efficacy had children found that they use smartphone 'once a day' and 'several times a day'. In particular, mothers who have low cognitive efficacy allowed their children to use smartphone, but mothers who have high cognitive efficacy set the use frequency to less than five times a week.

The difference in the average use hours of smartphone depending on each different level of child-rearing efficacy was investigated. The group that has low cognitive efficacy and emotional efficacy mostly replied 'one hour', whereas the group that has high cognitive efficacy and emotional efficacy replied 'three hours'. It was found that the more mothers have skillful parental roles, problem-solving capability, and positive identity about parents' roles, the more they are able to control the smartphone use of their children, and the more they recognize the positive sides of smartphone. 


\section{Table 4. The Differences in the Actual State of Smartphone use of Infants and Young Children Depending on Different Groups of Child-rearing Efficacy}

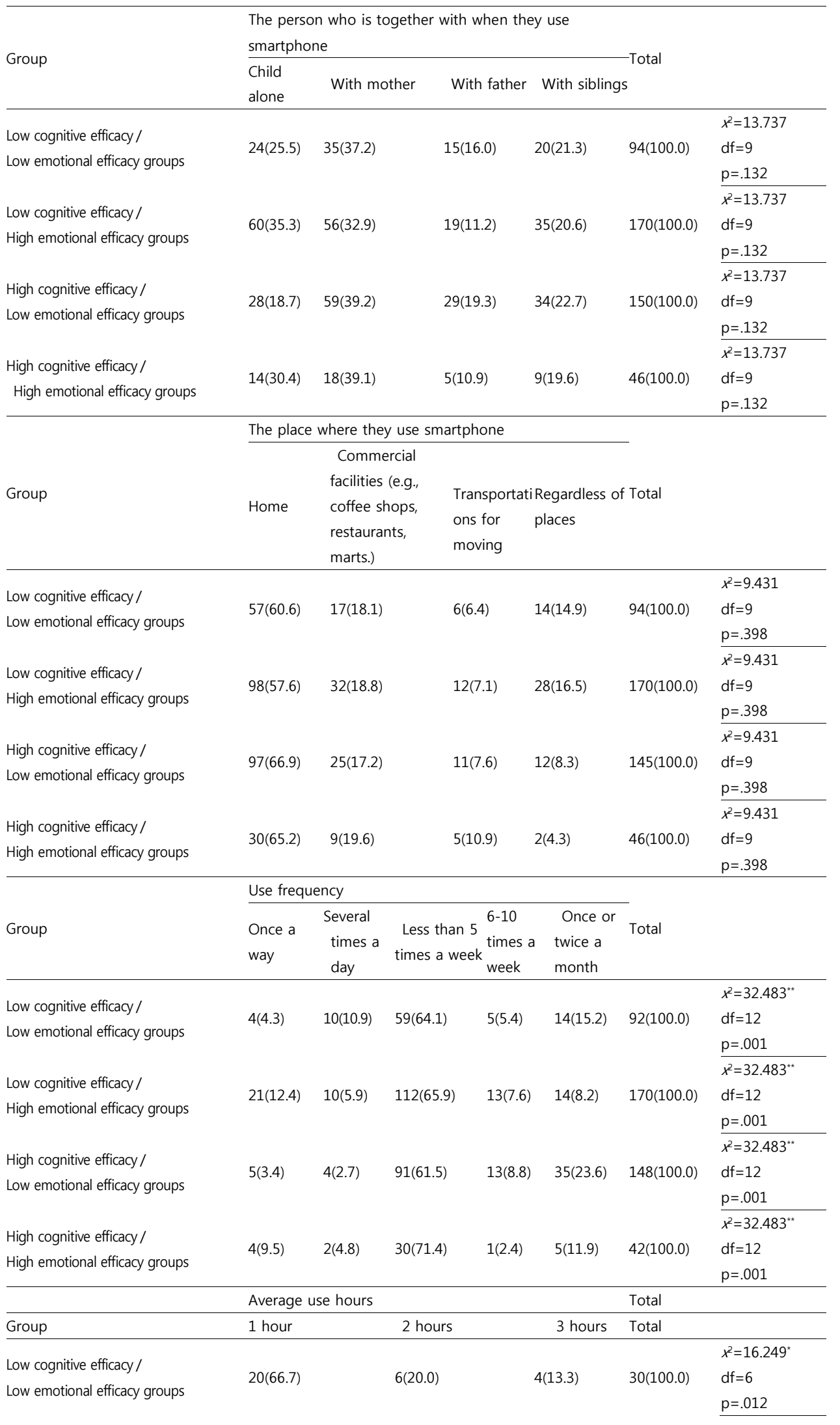




\begin{tabular}{|c|c|c|c|c|c|}
\hline \multirow[b]{2}{*}{$\begin{array}{l}\text { Low cognitive efficacy / } \\
\text { High emotional efficacy groups }\end{array}$} & \multirow[b]{2}{*}{$42(64.6)$} & \multirow[b]{2}{*}{$19(29.2)$} & \multirow[b]{2}{*}{$4(6.2)$} & \multirow[b]{2}{*}{$65(100.0)$} & \multirow[b]{2}{*}{$\begin{array}{l}x^{2}=16.249^{*} \\
d f=6 \\
p=.012\end{array}$} \\
\hline & & & & & \\
\hline & & & & & $x^{2}=16.249^{*}$ \\
\hline High cognitive efficacy / & $31(70.5)$ & $8(18.2)$ & $5(11.4)$ & $44(100.0)$ & $d f=6$ \\
\hline Low emotional efficacy groups & & & & & $p=.012$ \\
\hline $\begin{array}{l}\text { High cognitive efficacy / } \\
\text { High emotional efficacy groups }\end{array}$ & $5(35.7)$ & $3(21.4)$ & $6(42.9)$ & 14(100.0) & $\begin{array}{l}x^{2}=16.249^{*} \\
d f=6 \\
p=.012\end{array}$ \\
\hline
\end{tabular}

\section{Conclusion and Proposal}

The purpose of this study is to investigate smart phone use condition of young children aged $0-5$, the mothers' perception of young children's smart phone use, and the role of parental efficacy in making difference in the smart phone use condition of infants and toddlers. And the summarized results are as below.

\subsection{Smart Phone Use Condition of Infants and Toddlers}

Infants and toddlers used smart phones most frequently at home with their mothers, and toddlers' use was more frequently occurred than that of infants, and infants and toddlers use smart phones 'less than 5 times a week' , with average 1hours a day. That means, as mentioned in preceding research [5], parents' possession of smart phones serves as an opportunity that infants and toddlers are exposed to smart phones. And mothers play a major role in raising young children, and smart phone use frequently takes place in houses where mothers and their kids spend a long time together. And the number of use is less than 5 times a week, with average 1hours, which shows that parents and their young children agreed to use smart phones about once a day for 1 hour. Therefore, it is concluded that most of the infants and toddlers use smart phones with their mothers. And this conclusion suggests that parents should teach proper use of smart phone to their young children. Also the research result that the more frequently young children use smart phones, the more they become addictive [6] indicates that an educational program for parent is needed for the purpose of observing a time limit and learning effective use of smart phone.

\subsection{Mothers' Perception of their Young Children's Smart Phone Use}

The desire of their children was the most powerful factor on smart phone use. And mothers thought their kids needed a smart phone because it could help them with their learning, but others opposed smart phone use because of its negative effects on children's physical and cognitive development. Mothers and kids enjoyed mainly cartoon animations but hardly used educational contents. The reasons why infants and toddlers want to use smart phones are that they are interested in smart phones and find it easy to use them because smart phones have a touch screen worked by fingers and are made in an intuitive and simple way. And there were some mothers who said smart phones could be a tool for learning; they believed educational contents supported cognitive education. On the other hand, mothers who considered smart phones unnecessary argued that the size of screen was small, and visible activities caused by long hours of smart phone use hindered development. That means mothers are aware of positive and negative aspects of smart phone: educational effect and game addiction. However, most of the infants and toddlers use smart phones on their own. Considering that they are not able to distinguish right and wrong, there is a chance to access harmful websites. Therefore, parents should actively intervene in smart phone use of their young children. 


\subsection{The Difference in Smart Phone use Condition of Infants and Toddlers according to Parental Efficacy of Mother}

The smart phone use based on parental efficacy of mother showed significant difference between the number of use and average use hours. This suggests that capable mothers who are able to solve problems and have positive identity as parents can control their children's smart phone use and are aware of positive aspects of smart phones. Parents' restraint makes the number and hours of smart phone use decrease, resulting in reduction of level of addiction, one of the negative aspects of smart phone. In other words, the constant attention and active participation of parents are absolutely required.

On the basis of this study, its limits and proposals for follow-up studies are as follows.

This study covers smart phone use condition of infants and toddlers, mothers' perception of smart phone use of their kids, and difference in smart phone use condition of infants and toddlers according to parental efficacy of mother. The use of smart phone has increased. And Korea, IT powerhouse of the world made it possible to spread smart phones at a quick pace, but, through this, people became indiscriminately exposed to them, not knowing proper use of them or prevention programs. Especially, infants and toddlers whose mothers have smart phones are also likely to use them, so mothers' modeling and exposure can be influential factors. Besides, autonomous nursing of mothers who don't know about harmful consequences from internet addiction can cause children's addiction to smart phones. It is urgent for parents to learn effective use of smart phones so that they accept smart phones critically, understand their advantages and disadvantages, and eventually act as good guides for their children. Indiscriminate exposure can lead to smart phone addiction, if young children and their parents are not aware of pros and cons of smart phones: proper use and frequency, a time limit, game, etc. The addiction can have influence on the social and emotional growth of infants and toddlers, so it is necessary to carry out prevention programs.

The limits of the study are firstly, this study chose mothers of young children in childhood education institutes located in D and I cities, so it is hard to generalize the results of the study.

Secondly, except for smart phone use condition, social and emotional factors should be considered as influential factors on smart phone use.

Thirdly, smart phone use condition probably can be seen in only Korea, an IT power. Comparison of the smart phone use in Korea and foreign countries is needed to make a study on program development considering pros and cons of Korean smart phones.

\section{References}

[1] Y. Kong, "New paradigm on Smart Phone Implication”, Communications policy, /http://dl.nanet.go.kr/SearchArtList.do, vol. 2, (2006), pp. 1-22.

[2] B. Kim, S. Yoon and H. Lee, "The Analysis for the Causes of Mobile Phone Addiction", NIA, Dce, /http://dl.nanet.go.kr/OpenFlashViewer.do, (2006), pp. 6-14.

[3] S. Kim and H. Kim, "A Study on Teenagers' Mobile Phone Addict”, KABS, /http://libproxy.wonkwang.ac.kr/90a6552/_Lib_Proxy_Url/www.riss.kr/link?id=A76338226, vol. 18, (2003), pp. 88-116.

[4] K. Yoo, M. Kim and E. Kim, "An Analysis of Contents and Interactions for the Educational Application on Smart-Phone and Tablet PC”, KOAECE, /http://libproxy.wonkwang.ac.kr/90a6552/_Lib_Proxy_ Url/www.riss.kr/link?id=A60072870, vol. 17, no. 1, (2012), pp. 169-194.

[5] W. Lee and Y. Sung, "Recognition of the mother in relation to the smartphone", KICCE, /http://www.kicce.re.kr/kor/publication/publication_V.jsp?bbscode=447\&sch_type=\&keyword=\&page_ num=1\&sch_bbsdate=\&menu_id=010302\&gcode=C\&scode, vol. 6, no. 1, (2012), pp. 20-38.

[6] D. J. Lee, "A study on mobile phone addiction of college students (D-College)", Journal of The Korea Society of Computer and Information, /http://libproxy.wonkwang.ac.kr/90a6552/_Lib_Proxy_Url /www.riss.kr/link?id=A76454056, vol. 12, no. 4, (2007), pp. 159-167.

[7] C. J. Lee, "Evolution of the smartphone and challenges", Korea Journal of Air-Conditioning and Refrigeeration Engineering, /http://libproxy.wonkwang.ac.kr/90a6552/_Lib_Proxy_Url/www.riss.kr/ link?id=A76557313, vol. 38, no. 11, (2009). 
[8] K. S. Cho, "Smartphones used for foreign Language Learning”, MALL, / http://libproxy.wonkwang.ac.kr /90a6552/_Lib_Proxy_Url/www.riss.kr/link?id=A95954107, vol. 12, no. 3, (2009), pp. 211-228.

[9] B. Choi, K. Cho, H. Yeon and M. Jeong, "Characteristics of Cellular Phone Use Adolescents research report”, KADO, /http://dl.nanet.go.kr/SearchDetailView.do?cn=MONO1200614929\&sysid=openap, (2005), pp. 05-08.

[10] E. Hyun, T. Kim, M. Cho and E. Park, "Young Chi1dren`s Parents` Perception of the Use of Digital Mobile Devices at Home”, Shinang-gwa-hakmun, / http://www.riss.kr/link?id=A82770240, vol. 16, no. 4, (2011), pp. 245-266.

[11] M. Hashemi and B. Ghasemi, “Using mobile phones in language learning/teaching”, Procedia Social and Behavioral Sciences, / http://libra.msra.cn/Publication/49674006/using-mobile-phones-in-languagelearning-teaching, vol. 15, (2011), pp. 2847-2951.

[12] J. E. Katz and P. Aspden, "Theories, Data, and Potential Impacts of Mobile Communications: A Longitudinal Analysis of U. S. National Surveys Technological Forecasting and Social Change”, / http://www.riss.kr/link?id=O7913613, vol. 57, (1998).
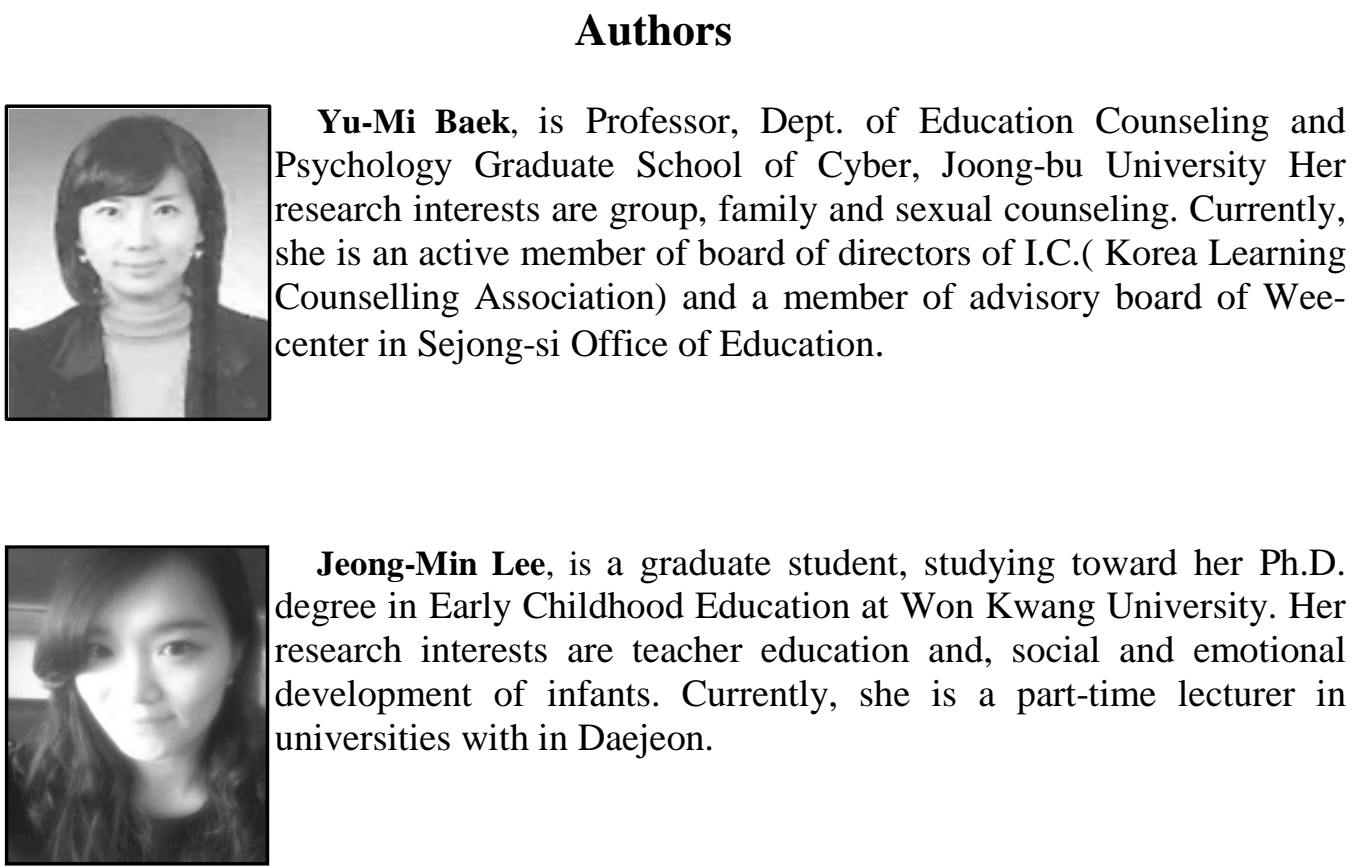

Jeong-Min Lee, is a graduate student, studying toward her Ph.D. degree in Early Childhood Education at Won Kwang University. Her research interests are teacher education and, social and emotional development of infants. Currently, she is a part-time lecturer in universities with in Daejeon.

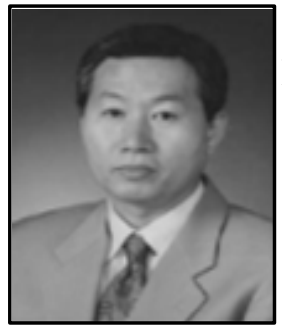

Kyu-Soo Kim, is a Professor, Department of Early Childhood Education, Wonkwang University at the Department of Early Childhood Development at Won Kwang University. His research work mainly focuses on early childhood educational policy and social development and education of infants. He has been a chair of KOAECE. and currently an active member of advisory board of KICCE. 